\title{
Proposed Amendments to the Wildlife Protection Law of the People's Republic of China
}

\author{
Li-hong Gao \\ Professor of Law School of Zhongnan University of Economics and Law, Vice President of China Society \\ of Environmental Resources Law, President of Hubei Province Society of Environmental Resources Law, \\ China
}

$\mathrm{Su} \mathrm{Da}$

Master of Environmental Law, Zhongnan University of Economics and Law, China

Received: November 2020

Accepted: November 2020

Cita recomendada. GAO, L., DA, S., Proposed Amendments to the Wildlife Protection Law of the People's Republic of China, dA. Derecho Animal (Forum of Animal Law Studies) 11/4 (2020). - DOI https://doi.org/10.5565/rev/da.539

\begin{abstract}
The outbreak of COVID-2019 has focused public attention on China's wildlife-related legal regimes, such as the regulatory regime for wildlife hunting and trade and the animal epidemic prevention regime, which is complex, with the Wildlife Protection Law as the core. On February 24, the standing committee of the National People's Congress (NPC) issued an emergency legal document, the Decision, which has the effect of banning wildlife consumption, guiding public awareness, and regulating the overall legal system, and directly initiates the revision of the Wildlife Protection Law. On 21 October 2020, the Wildlife Protection Law (draft amendment) was announced. Based on the Decision and the Draft, this paper believes that in future revisions of the Wildlife Protection Law the main focus should be on changing the form of state ownership, establishing a pluralistic protection system, increasing legal penalty, coordinating with other legislation, and concern for individual animal welfare.
\end{abstract}

Keywords : Wildlife in China; Animal law; Emergency legislation; China.

Resumen - Propuesta de enmiendas a la Ley de Protección de la Vida Silvestre de la República Popular China

El brote de COVID-2019 ha puesto la atención del público en el régimen jurídico relacionado con la vida silvestre de China, como el régimen regulatorio de caza y comercio de fauna silvestre y el régimen de prevención de epidemias animales, que es complejo, centrándose en la Ley de Protección de la Vida Silvestre. El 24 de febrero, el Comité permanente de la Asamblea Popular Nacional (NPC) emitió un acto legislativo de emergencia, la Decisión, que tiene el efecto de prohibir el consumo de vida silvestre, orientar la conciencia pública y regular el régimen jurídico general, e inicia directamente la revisión de la Ley de Protección de la Vida Silvestre. El 21 de octubre de 2020, se anunció la Ley de Protección de la Vida Silvestre (proyecto de enmienda). En base a la Decisión y al Proyecto, este artículo considera que en futuras revisiones de la Ley de Protección de Vida Silvestre, el enfoque principal debería estar en cambiar la forma de propiedad estatal, establecer un sistema de protección plural, incrementar las sanciones jurídicas, coordinarse con otras leyes y preocuparse por el bienestar animal individual.

Palabras clave : Vida silvestre en China; Derecho Animal; Legislación de emergencia; China. 


\section{Introduction}

The outbreak of COVID-2019 has put China's wildlife protection legal system in the national and even international spotlight. From the focus of public opinion on the consumption of wild animals after the epidemic, there is a fatal flaw in China's wildlife protection legal system: both the purpose of legislation and legal positioning regarding wild animals as resources for human use. For example, Article 3 of the Wildlife Protection Law stipulates that "wildlife resources belong to the state" and Article 4 stipulates that the legal principle is to "give priority to the protection of wildlife, regulate their utilization and supervision." ${ }^{1}$ The Wildlife Protection Law is the foundation and core of wildlife protection legal system, and it is inevitable that each specific regime will fail because of the deviation in the positioning of the law as the core. This is not the first time that this problem has been brought to the attention of Chinese scholars, who have long been concerned about it. ${ }^{2}$ Correspondingly, in response to the epidemic, on February 24, the 16th meeting of the Standing Committee of the 13th NPC deliberated and issued the Decision, which has significant implications for the future development of China's wildlife protection legal system. ${ }^{3}$ Subsequently, on 21 October 2020, the new Wildlife Protection Law (draft amendment) was announced to the public, and public comments were solicited. ${ }^{4}$ The Draft revised law highlights the concern for "animal epidemic prevention", adds the legal principle of risk prevention, and improves legal regimes. However, some problems about the inappropriate utilization of wild animals, such as animal performances, have not been completely eliminated, and the principle of animal welfare has not been introduced into the legal text.

Therefore, through the textual analysis of the Decision, it is possible to grasp the direction of the future revision of China's wildlife protection law and trace the shortcomings of the previous wildlife protection legal system. At the same time, a new wildlife protection legal system is presented based on the combing of the Draft. This paper identifies the deviations of the current legal system from a macro perspective by combing through the existing regulations related to wildlife protection in China. It also analyzes the function and position of the Decision in the future legislative activities and proposes a holistic approach to revise the whole system by taking into account China's special conditions and the Draft.

\section{China's current wildlife protection legal system and its deficiencies}

It must be affirmed that there are many laws regulating wildlife protection in China, but the legislative value positioning of the overarching Wildlife Protection Law is deviated, resulting in the actual situation in which the utilization of wildlife is more important than the concept of protection, and economic value is emphasized more than ecological values.

In order to provide as comprehensive an analysis as possible, we have organized the national-level laws involved in wildlife conservation in China as shown in the annex I ${ }^{5}$.

It can be seen that China's wildlife protection legal system is relatively complete, supported by a number of laws that are at the core of the national legislative system. However, as Mr. Liang Zhiping said, the ideology of the rule of law in China is anthropocentric. ${ }^{6}$ This concept is projected on the law, on the animals, which is the purpose of China's current animal legislation, and the common feature they show is "emphasis on utilization, slight protection" and "the divergence between legislation and law enforcement." ${ }^{7}$ The open or semi-open sale of state-protected wildlife in individual local markets in recent years indicates that legal provisions prohibiting or restricting hunting are not functioning properly. ${ }^{8}$ However, it should be made clear

\footnotetext{
${ }^{1}$ See Article 3 and 4 of the Wildlife Protection Law of the People's Republic of China（2018）: http://www.gov.cn/bumenfuwu/2012$11 / 13$ /content 2601275.htm

${ }^{2}$ A November 2018 lecture by Chinese scholar Liang Zhi-ping provides a more comprehensive and systematic discussion of the core issues of China's wildlife protection law. For a detailed discussion, see LIANG, Z. and JIN, Z., Parrot trade and tiger bone use - the legal dilemma of wildlife protection in China, Law and ethics, 2 (2019) 193-225.

${ }^{3}$ See Decision of the Standing Committee of the National People's Congress on a Comprehensive Ban on Illegal Wildlife Trade, the Eradication of Malpractices of Indiscriminate Eating of Wild Animals, and the Effective Protection of People's Lives and Health (The Decision): https://www.pkulaw.com/CLI.1.339750.

${ }^{4}$ See web of China National People's Congress (NPC):

http://www.npc.gov.cn/flcaw/userIndex.html?lid=ff808081752b7d43017543fdc24714c5. Hereinafter referred to as the Draft.

${ }^{5}$ In addition to these laws, China has a large number of regulations that deal with wildlife management and protection, about 230 according to the author's statistics, which are omitted here due to the large number

${ }^{6}$ See LIANG, Z. and JIN, Z., Parrot trade and tiger bone use - the legal dilemma of wildlife protection in China, Law and ethics, 2 (2019) 193-225.

${ }^{7}$ Scholar Liu Zhixin also believes that existing wildlife protection laws are full of exceptions. See LIU, Z., Reinventing the Principles of the Wildlife Protection Law, Administrative Law Review, 4 (2020) 83-94.

${ }^{8}$ See XUE, K., The Double Failure of Wildlife Industry Regulation and Its Correction: A Legal Analysis of Illegal Wildlife Chains,
} 
that in the Chinese legal concept, protection and utilization are not a conflicting, antagonistic relationship. ${ }^{9}$

\subsection{The purpose of the relevant legislation remains anthropocentric}

Article 1 of the Wildlife Protection Law stipulates, "This law is enacted for the purpose of protecting wildlife, saving precious and endangered wildlife, maintaining biodiversity and ecological balance, and promoting the construction of ecological civilization." ${ }^{10}$ If we look at the text alone, such legislation should be oriented towards legal norms with conservation as the ultimate goal. However, Article 2 stipulates that "The wildlife protected by the provisions of this Law refers to precious and endangered terrestrial and aquatic wildlife and terrestrial wildlife of important ecological, scientific and social value." ${ }^{11}$ In effect, this excludes from protection wildlife that is not endangered, valuable, or of any of the above three values.

The Wildlife Protection Law has undergone numerous revisions until 2009, when its legislative purpose was amended to "This Law is enacted to protect and save precious and endangered wildlife, to protect, develop and rationally utilize wildlife resources, and to maintain ecological balance." ${ }^{12}$ And until 2016, only amended to "in order to protect wildlife, save precious and endangered wildlife, maintain biodiversity and ecological balance, and promote the construction of ecological civilization, the development of this law." ${ }^{13}$ As the overarching law that should reflect a reshaping of the future of human-animal relations, a reflection brought about by the outbreak of the epidemic.

\subsection{Legislative principles focus on the resource attributes of animals}

Article 3 of the current Wildlife Protection Law emphasizes first that "wildlife resources belong to the State," ${ }^{14}$ while the principle is "to give priority to protection, regulate utilization and strict supervision, encourage scientific research on wildlife, cultivate citizens' awareness of wildlife protection, and promote the harmonious development of man and nature." 15 The "regulate utilization" actually reflects the legislator's ambiguous attitude towards the utilization of wildlife.

And as in Article 27: "Those who sell or use wild animals that are not under state protection shall provide proof of the legal origin of the hunting, import and export." ${ }^{16}$ Article 22 states: "Anyone who hunts wild animals not under state protection shall obtain a hunting license issued by the wildlife protection department of the local government at or above the county level in accordance with the law, and shall be subject to the management of the hunting quota." ${ }^{17}$ This confirms that the legislator has not yet made a breakthrough in the resource utilization attributes of the animals, which is the value objective that needs to be achieved by the Wildlife Protection Law. In addition, Articles 29 and 30 recognize the feasibility of using wild animals as medicinal materials and foodstuffs. ${ }^{18}$

\subsection{Risk of failure of specific legal regimes}

China currently has a classification and grading regime for wildlife conservation, but the specific protection lists are updated every five years. ${ }^{19}$ In contrast, according to the government information disclosure

\footnotetext{
Law and Economy, 4 (2020) 99-107.

${ }^{9}$ See LIANG, Z., On the Legal Regulation of Common Wildlife Use, Administrative Law Review, 4 (2020) 95-104.

${ }^{10}$ See Article 1 of the Wildlife Protection Law of the People's Republic of China (2018): http://www.gov.cn/bumenfuwu/201211/13/content 2601275.htm

${ }^{11}$ See Article 2 of the Wildlife Protection Law of the People's Republic of China (2018): http://www.gov.cn/bumenfuwu/201211/13/content 2601275.htm

12 See Article1 of the Wildlife Protection Law of the People's Republic of China (2009): http://www.iolaw.org.cn/showNews.aspx?id=24345

${ }^{13}$ See Article1 of the Wildlife Protection Law of the People's Republic of China (2016): http:/www.npc.gov.cn/wxzl/gongbao/201608/22/content 1995643.htm

${ }^{14}$ See Article 3 of the Wildlife Protection Law of the People's Republic of China (2018): http://www.gov.cn/bumenfuwu/201211/13/content 2601275.htm

${ }^{15}$ See Article 4 of the Wildlife Protection Law of the People's Republic of China (2018): http://www.gov.cn/bumenfuwu/201211/13/content_2601275.htm

${ }^{16}$ See Article 27 of the Wildlife Protection Law of the People's Republic of China (2018): http://www.gov.cn/bumenfuwu/201211/13/content_2601275.htm

${ }^{17}$ See Article 22 of the Wildlife Protection Law of the People's Republic of China (2018): http://www.gov.cn/bumenfuwu/201211/13/content 2601275.htm

18 See Article 29 and 30 of the Wildlife Protection Law of the People's Republic of China (2018): http://www.gov.cn/bumenfuwu/2012-11/13/content 2601275.htm

${ }^{19}$ See Article 10 of the Wildlife Protection Law of the People's Republic of China (2018): http://www.gov.cn/bumenfuwu/2012-
} 
regime, the National List of Key Wildlife Protection was only adjusted in 1993 and $2003 .{ }^{20}$ The pangolin was urgently adjusted from a Class II protected animal to a Class I protected animal after the outbreak of the epidemic. The latest revision was initiated on June $19 .{ }^{21}$ If animals are thus valued and protected sequentially, there is a risk that the scope of protection misses wildlife that is ecologically important but not timely assessed by the assessment system. Habitat protection is also in the form of assessment and publishing lists, and there is a similar risk of failure. ${ }^{22}$

Articles 20 to 24 regulate no-hunting areas, no-hunting periods, hunting practices, and hunting qualifications, ${ }^{23}$ but when the actual regime was in effect, such regulation was extremely lax, and as of January 22 after the outbreak, pheasants, rabbits, and wild pigs were still being sold as foodstuffs in South China's seafood markets. ${ }^{24}$ However, the decision has imposed a complete ban on the above-mentioned activities.

Articles 29 and 30, which have been criticized by animal protectors, stipulate that "the utilization of wild animals and their products shall be based on artificial breeding of populations, conducive to the conservation of wild populations, in line with the requirements of the construction of ecological civilization, respect for social morality, compliance with laws and regulations and relevant state regulations," "Prohibit the production and operation of food products made from state-protected wild animals and their products, or food products made from non-state-protected wild animals and their products without proof of legal origin." 25 Although there are many restrictions in the law, most operators do not strictly adhere to them out of economic interests, especially the requirement of "contributing to the conservation of wild populations," which is null and void.

In addition to this, there is a total failure of the regime in the management process of transport, trade, and exit of wildlife.

\section{Key elements of the Decision and its Role}

The outbreak of COVID-2019 was a direct consideration of the Decision, and here I have organized the main elements of the Decision with other existing laws in the following table.

Table 2: Key elements of the Decision ${ }^{26}$

\begin{tabular}{|c|c|c|}
\hline Object & Specific provisions & $\begin{array}{l}\text { Interface with } \\
\text { other laws }\end{array}$ \\
\hline \begin{tabular}{l}
\multicolumn{1}{c}{ Wildlife } \\
prohibited from being \\
hunted, traded, \\
transported, or eaten \\
under existing laws
\end{tabular} & $\begin{array}{l}\text { Where the Wildlife Protection Law and } \\
\text { other relevant laws prohibit the hunting, } \\
\text { trading, transporting, or eating of wildlife, it } \\
\text { must be strictly prohibited. }\end{array}$ & $\begin{array}{l}\text { Aggravation of } \\
\text { penalties on the basis } \\
\text { of existing legal } \\
\text { provisions }\end{array}$ \\
\hline $\begin{array}{l}\text { Terrestrial } \\
\text { wild animals of } \\
\text { important ecological, } \\
\text { scientific, and social } \\
\text { value and other } \\
\text { captive-bred } \\
\text { terrestrial } \\
\text { animals wild } \\
\text { terrestrial and }\end{array}$ & $\begin{array}{l}\text { A total ban on the consumption of } \\
\text { State-protected "terrestrial wildlife of } \\
\text { ecological, scientific and social importance" } \\
\text { and other terrestrial wildlife, including } \\
\text { captive-bred terrestrial wildlife. } \\
\text { A total ban on the hunting, trading, and } \\
\text { transport of terrestrial wildlife that grows and } \\
\text { breeds naturally in the wild for food purposes. }\end{array}$ & $\begin{array}{l}\text { Penalties are } \\
\text { applied by reference } \\
\text { to the relevant } \\
\text { provisions of the laws } \\
\text { in force. }\end{array}$ \\
\hline
\end{tabular}

11/13/content 2601275.htm

${ }^{20}$ See Government Network of the State Forestry and Grassland Administration: http://www.forestry.gov.cn/main/3954/content1063883.html

21 See Notice of Public Comment on the National List of Key Protected Wildlife: http://www.forestry.gov.cn/main/153/20200619/092731170435586.html

${ }^{22}$ See Article 12 of the Wildlife Protection Law of the People's Republic of China (2018): http://www.gov.cn/bumenfuwu/201211/13/content_2601275.htm

23 See Article 20,21,22,23,24 of the Wildlife Protection Law of the People's Republic of China (2018): http://www.gov.cn/bumenfuwu/2012-11/13/content_2601275.htm

${ }^{24}$ See People's Daily Press. People's Daily (Jan. 22): http://paper.people.com.cn/rmrb/html/2020-09/22/nbs.D110000renmrb_01.htm

25 See Article 29 and 30 of the Wildlife Protection Law of the People's Republic of China (2018): ttp://www.gov.cn/bumenfuwu/2012-11/13/content_2601275.htm

${ }^{26}$ See Decision of the Standing Committee of the National People's Congress on a Comprehensive Ban on Illegal Wildlife Trade, the Eradication of Malpractices of Indiscriminate Eating of Wild Animals, and the Effective Protection of People's Lives and Health (The Decision): https://www.pkulaw.com/CLI.1.339750. 


\begin{tabular}{|c|c|c|}
\hline $\begin{array}{l}\text { animals that grow and } \\
\text { reproduce naturally } \\
\text { in the wild. }\end{array}$ & & \\
\hline $\begin{array}{l}\text { Animals } \\
\text { included in the } \\
\text { Catalogue of Animal } \\
\text { and Poultry Genetic } \\
\text { Resources }\end{array}$ & $\begin{array}{l}\text { The animals included in the Catalogue } \\
\text { of Animal and Poultry Genetic Resources are } \\
\text { domestic animals and poultry, and the } \\
\text { provisions of the Livestock Husbandry Law } \\
\text { are applicable. } \\
\text { The animal husbandry and veterinary } \\
\text { administrative departments under the State } \\
\text { Council draw up and publish the Catalogue of } \\
\text { Animal and Poultry Genetic Resources in } \\
\text { accordance with the law. }\end{array}$ & $\begin{array}{l}\text { The provisions } \\
\text { of the Animal } \\
\text { Husbandry } \\
\text { apply. }\end{array}$ \\
\hline \begin{tabular}{lr}
\multicolumn{1}{c}{ Wildlife for } \\
scientific, \\
and & exhibitition \\
purposes &
\end{tabular} & $\begin{array}{l}\text { Where the non-food utilization of wild } \\
\text { animals is required for scientific research, } \\
\text { medicinal utilization, display or other special } \\
\text { circumstances, strict approval and quarantine } \\
\text { inspection shall be carried out in accordance } \\
\text { with the relevant national regulations. The } \\
\text { State Council and its relevant competent } \\
\text { departments shall promptly formulate and } \\
\text { improve regulations on the approval, } \\
\text { quarantine, and inspection of the non-food } \\
\text { utilization of wild animals, and strictly enforce } \\
\text { them. }\end{array}$ & 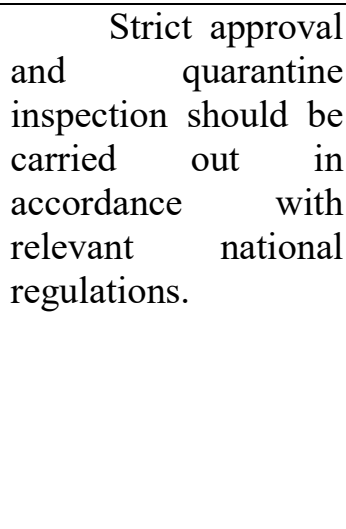 \\
\hline
\end{tabular}

The Decision is emergency legislation in response to public demand and outbreaks of epidemics, and therefore focuses on the main gaps in the legal regime that have been exposed in the wake of the epidemic. As a whole, the Decision is comprehensive in nature, as reflected in the following aspects.

\subsection{Comprehensiveness in relation to the range of animals}

According to Table 2, we can see that the Decision has adjusted the scope of wild animals involved in various fields, including those used for scientific research and experimentation, animal husbandry, and those protected by the current Wildlife Protection Law, basically covering all wild animal species that are closely related to human production and life in the current social life.

As an urgent legal document, the Decision extends the scope of the ban to state-protected "terrestrial wildlife of important ecological, scientific and social value" as well as other terrestrial wildlife, including captive-bred terrestrial wildlife. It responds to public expectations at the legal level and fills in the gaps in the Wildlife Protection Law.

\subsection{Comprehensiveness in a double boost to legislation and enforcement}

The Decision reflects the dual promotion of legislation and enforcement. It can be summarized as follows: (a) stricter approval and quarantine inspection of non-food wildlife; (b) greater enforcement and management by people's governments and competent authorities at all levels and greater public guidance; and (c) economic policy to adjust the industrial structure and compensate animal breeders.

\section{3. Overall consolidation of existing laws in various fields}

As shown in Table 1, there are many laws relating to wildlife protection in China, and institutional failures are not the result of the omission of one law, but rather the deficiencies of the legal regime as a whole. The Decision, on the other hand, focuses on the coordination of the various laws, such as references to administrative law, animal husbandry law, and legislation related to laboratory animals. Significantly, the Decision emphasizes the emphasis on penalties for wildlife-related violations, which is the future direction of the revision of China's wildlife protection law and the reform of related regimes. 
The Wildlife Protection Law, which is China's main legislation in the field of wildlife protection, was implemented in March 1989 and has been amended four times, in August 2004, August 2009, July 2016, and October 2018. The Decision also indicates that vigorous revision of the Wildlife Protection Law is on the agenda, and in general the following four major issues should be paid attention to during the revision process.

The legislative purpose of the Wildlife Protection Law should add "safeguarding the life and health of citizens" to the existing "This law is enacted for the purpose of protecting wildlife, saving precious and endangered wildlife, maintaining biodiversity and ecological balance, and promoting the construction of ecological civilization." 27 To summarize, biodiversity protection is the direction of development of the Wildlife Protection Law, which emphasizes species diversity and ecosystem diversity, and the current protection regime is limited to the protection of individual animals, while neglecting fauna protection and animal habitat protection. To address these issues, the next legislative work should focus on linking wildlife protection legislation with that of nature reserves and Yangtze River protection.

The current Wildlife Protection Law focuses on the utilization of animal resources and is lax in its approach to conservation, with an important misconception being the widespread belief that state ownership is conducive to protection and management. The guiding principle of the Wildlife Protection Law should be a change in the direction of strengthening ecological values.

The Wildlife Protection Law should serve as the overarching, guiding, and basic law in the field of wildlife protection, and in addition to the Wildlife Protection Law fauna protection laws should be formulated for some important fauna, rather than thinking that the enactment of a Wildlife Protection Law can solve all wildlife protection problems once and for all. The United States has also enacted a series of species protection laws in addition to the Endangered Species Protection Act, such as the Marine Mammal Protection Act, the Migratory Bird Protection Act, and the Bald and Golden Eagle Protection Act. In short, the animal protection legal regime needs to be continuously improved.

In terms of the scope of legislation, the Wildlife Protection Law should implement the concept of integral and equal protection, with priority given to endangered species, but the law should provide protection for all wildlife. However, the existing Wildlife Protection Law still only protects some of the precious, endangered, and three other kinds of wild animals (those with important ecological, scientific and social values). Comprehensive protection at the level of fasting on wildlife, as stated in the Decision, is the direction of development of the legal regime for animal protection, but this is a long process.

\section{Key elements of the Draft and its development}

On October 21, NPC released the Draft, and the deadline for public comment was November 19, 2020. According to the revision instructions released by the NPC, the revised principles of the Draft are: "First, the people and life are paramount, and the prevention of public health risks is given top priority; second, comprehensive and systematic protection is insisted upon, and the scope of wildlife protection and management is expanded to implement full-chain management; third, the focus is highlighted, and source prevention and control, prohibition of indiscriminate consumption of wildlife, and the protection of wildlife is given top priority. Strictly cracking down on illegal wildlife markets and trade; fourth, adhering to the problem-oriented, should be corrected, focusing on the outstanding problems faced in the field of wildlife protection, and further improving the design of relevant legal regimes." ${ }^{28}$ Overall, the Draft takes the situation as an opportunity to highlight the improvement of the legal system for animal epidemic prevention and public safety. It is a comprehensive and systematic legal expression of the relevant content of the Decision. The changes to the Draft can be summarized in the following aspects.

\subsection{Incorporating risk prevention principles to build a public health risk prevention system}

The occurrence of epidemics has made the establishment of a wildlife-related public health and safety system a necessity. In addition to adding "prevention of public health risks" to Article $1,{ }^{29}$ the draft adds "risk prevention principle" to Article 4 about legal principle and adds "promotion of harmonious development of man and nature" to the fourth legal principle. ${ }^{30}$ The new Article 16 is amended to read "Harmonious

\footnotetext{
${ }^{27}$ See Article 1 of the Wildlife Protection Law of the People's Republic of China (2018): http://www.gov.cn/bumenfuwu/201211/13/content_2601275.htm

${ }^{28}$ See web of China National People's Congress (NPC): http://www.npc.gov.cn/wxzl/gongbao/2016-08/22/content_1995719.htm.

${ }^{29}$ See Article 1 of the Draft: http://www.npc.gov.cn/flcaw/userIndex.html?lid=ff808081752b7d43017543fdc24714c5

${ }^{30}$ See Article 4 of the Draft:
} 
coexistence of man and nature." ${ }^{31}$

In the specific regimes, Article 16 details the responsibility of the governmental departments of health and sanitation for the prevention and control of epidemic diseases of wild animals, and stipulates the responsibilities of practitioners in reporting, prevention, monitoring, and harmless disposal measures. ${ }^{32}$

At the same time, Article 31 of the Draft prohibits the consumption of wild animals and the hunting, trading, and transporting of naturally-grown wild animals for food purposes, which is an explicit legal fixation of the Decision. ${ }^{33}$ At the same time, the Draft removes the previous permission for activities involving food made from non-priority wild animals and their products of legal origin. ${ }^{34}$

Article 36 details the import and export quarantine regime, ${ }^{35}$ and Article 39 emphasizes the reference to the Epidemic Prevention Law. ${ }^{36}$

In Article 10 on the wildlife protection list regime, the Draft gives local government departments the power to formulate specific management regulations in accordance with the need to prevent public health risks and maintain biosecurity and ecological safety. ${ }^{37}$

Among them, it is worth mentioning that those who consume or illegally purchase for consumption key protected wildlife, terrestrial wildlife, and their products of ecological, scientific, and social value are subject to a fine of not less than two times and not more than twenty times their value, and a social credit record regime has been introduced meaning that those who violate these articles will be recorded and made public through newspapers, announcements, and the Internet. Those who consume or purchase other terrestrial animals and their products for the same purpose are subject to a fine of not less than one and not more than ten times their value. ${ }^{38}$

\subsection{Establishing a joint law enforcement, investigation, and inspection system}

The legal system for wildlife protection in China faces a double risk of failure in its operation. The external risk lies in the test of the dynamism of the legal system brought about by the increasingly complex environment, while the internal risk mainly lies in the shirking and avoidance of responsibilities brought about by the independence of the legislative, enforcement, and judicial departments.

The overlapping responsibilities of different government departments are mainly in the management and inspection of wildlife hunting, trading, and transportation. The Draft makes stricter and more comprehensive provisions for the above-mentioned wildlife-related activities, including Article 6, "Illegal hunting, transporting, and trading of wildlife are prohibited. Illegal consumption of wild animals is prohibited." ${ }^{39}$ and Article 23 "Hunting licenses must be registered." 40 The new Article 25 is added about the prohibition and restriction of large-scale killing and capturing of other terrestrial wild animals in the wild. ${ }^{41}$ Article 26 adds three animals (of social, scientific, and ecological value) and local key protected animals to the breeding permit regime. ${ }^{42}$

Article 35 provides for the establishment of a joint law enforcement mechanism and a joint investigation

\footnotetext{
http://www.npc.gov.cn/flcaw/userIndex.html?lid=ff808081752b7d43017543fdc24714c5

${ }^{31}$ See Article 16 of the Draft:

http://www.npc.gov.cn/flcaw/userIndex.html?lid=ff808081752b7d43017543fdc24714c5

${ }^{32}$ See Article 16 of the Draft:

http://www.npc.gov.cn/flcaw/userIndex.html?lid=ff808081752b7d43017543fdc24714c5

${ }^{33}$ See Article 31 of the Draft:

http://www.npc.gov.cn/flcaw/userIndex.html?lid=ff808081752b7d43017543fdc24714c5

${ }^{34}$ See Article 31 of the Draft:

http://www.npc.gov.cn/flcaw/userIndex.html?lid=ff808081752b7d43017543fdc24714c5

${ }^{35}$ See Article 36 of the Draft:

http://www.npc.gov.cn/flcaw/userIndex.html?lid=ff808081752b7d43017543fdc24714c5

${ }^{36}$ See Article 39 of the Draft:

http://www.npc.gov.cn/flcaw/userIndex.html?lid=ff808081752b7d43017543fdc24714c5

37 See Article 10 of the Draft:

http:/www.npc.gov.cn/flcaw/userIndex.html?lid=ff808081752b7d43017543fdc24714c5

${ }^{38}$ See Article 54 of the Draft:

http://www.npc.gov.cn/flcaw/userIndex.html?lid=ff808081752b7d43017543fdc24714c5

${ }^{39}$ See Article 6 of the Draft:

http://www.npc.gov.cn/flcaw/userIndex.html?lid=ff808081752b7d43017543fdc24714c5.

${ }^{40}$ See Article 23 of the Draft:

http://www.npc.gov.cn/flcaw/userIndex.html?lid=ff808081752b7d43017543fdc24714c5.

${ }^{41}$ See Article 25 of the Draft:

http://www.npc.gov.cn/flcaw/userIndex.html?lid=ff808081752b7d43017543fdc24714c5.

${ }^{42}$ See Article 26 of the Draft:

http:/www.npc.gov.cn/flcaw/userIndex.html?lid=ff808081752b7d43017543fdc24714c5.
} 
and inspection system. ${ }^{43}$ Article 7 also provides for the establishment of a joint law enforcement coordination mechanism to deal with illegal transport and trade of wild animals. ${ }^{44}$ The basic logic is shown in the table below:

Table 3: Joint enforcement, investigation, and inspection system ${ }^{45}$

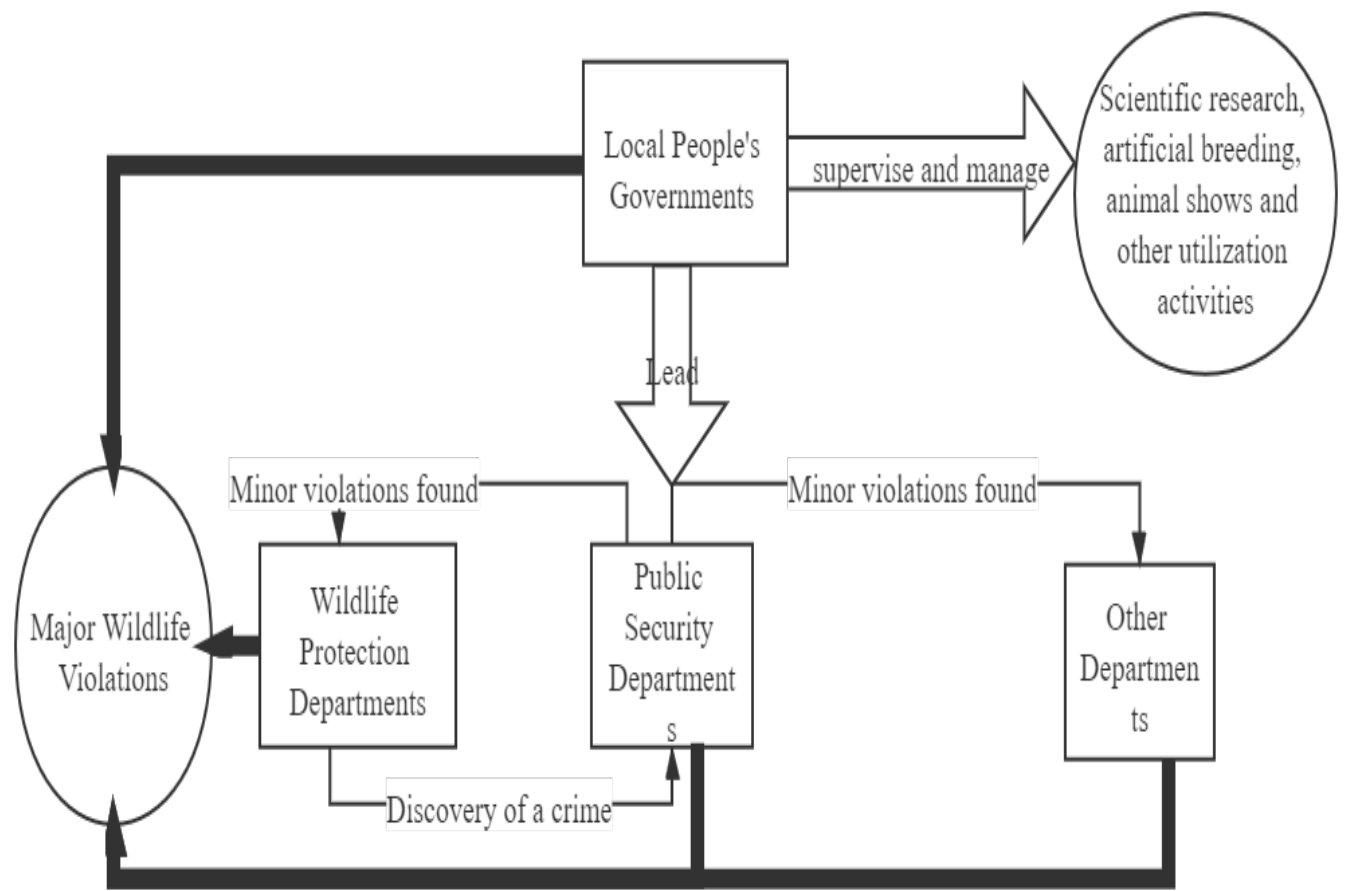

In particular, Article 7 emphasizes that local people's governments are "responsible for the protection of wildlife within their administrative regions" in their daily work. ${ }^{46}$ The responsibilities of various departments have also been detailed, mainly the supervision and inspection of illegal aspects of trade and transportation by road and other transportation departments. Article 12 adds the protection and management of wild animals in nature reserves to the competent wildlife protection departments. ${ }^{47}$

Article 36 stipulates the power of on-site inspection by relevant departments. ${ }^{48}$ At the same time, the Draft also reflects the importance of local autonomy, such as the specific management provisions of the wildlife protection list in Article 10, and the local legislative power for wildlife protection in Article 45. ${ }^{49}$ Meanwhile, Article 15 adds "the state strengthens the capacity building of wildlife sheltering and rescue" (with requirements for funding, places, personnel, tools, etc.). ${ }^{50}$

\subsection{Shifting the legislative purpose to harmonious coexistence of man and nature}

The most striking feature of the Draft is that it changes the legislative purpose from "harmonious development of man and nature" to "harmonious coexistence of man and nature," which is also the

\footnotetext{
${ }^{43}$ See Article 35 of the Draft:

http://www.npc.gov.cn/flcaw/userIndex.html?lid=ff808081752b7d43017543fdc24714c5.

${ }^{44}$ See Article 7 of the Draft:

http://www.npc.gov.cn/flcaw/userIndex.html?lid=ff808081752b7d43017543fdc24714c5.

45 This form is made in accordance with the specific provisions of article 35 of the Draft:

http://www.npc.gov.cn/flcaw/userIndex.html?lid=ff808081752b7d43017543fdc24714c5.

${ }^{46}$ See Article 7 of the Draft:

http://www.npc.gov.cn/flcaw/userIndex.html?lid=ff808081752b7d43017543fdc24714c5.

${ }^{47}$ See Article 12 of the Draft:

http://www.npc.gov.cn/flcaw/userIndex.html?lid=ff808081752b7d43017543fdc24714c5.

${ }^{48}$ See Article 36 of the Draft:

http://www.npc.gov.cn/flcaw/userIndex.html?lid=ff808081752b7d43017543fdc24714c5.

${ }^{49}$ See Article 10 and 45 of the Draft:

http://www.npc.gov.cn/flcaw/userIndex.html?lid=ff808081752b7d43017543fdc24714c5.

${ }^{50}$ See Article 15 of the Draft:

http:/www.npc.gov.cn/flcaw/userIndex.html?lid=ff808081752b7d43017543fdc24714c5.
} 
requirement and realization of the concept of ecological civilization in China today. ${ }^{51}$ This is a legal reflection of China's past attitudes towards the use of wildlife resources.

First of all, in terms of the scope of animal protection, Article 2 sets a bottom line by adding "the management of other terrestrial wildlife abide by this Law," aiming to weave a tight net of legal protection to prevent wild animals from being infringed upon because they are not within the scope of protection. ${ }^{52}$ Article 10 removes the requirement that the wildlife protection list be adjusted and published every five years and changes it to the principle of five years, with the possibility of revision at any time if necessary, and establishes a relevant scientific evaluation committee.$^{53}$ Each department has the right to formulate regulations based on "the need to prevent public health risks and maintain biosecurity and ecological safety" and submit them to the State Council for approval. ${ }^{54}$

As for the habitat protection regime, there are also more improvements. For example, in Article 11, the investigation, monitoring and evaluation of wild animals and their habitats, the content of "epidemic sources of wildlife diseases and their distribution" is added; ${ }^{55}$ in Article 13, the avoidance of important habitats for wildlife is emphasized in the selection of sites for various construction projects. ${ }^{56}$

Article 29 adds detailed provisions on the National Catalogue of Animal and Poultry Genetic Resources. ${ }^{57}$ The Draft has already reflected the coordination, convergence, and leading role of the Wildlife Protection Law in the whole animal protection legal system. Animal genetic resources are related to biosecurity and national security, so the Draft also adds a new Article 38, which prohibits the provision of genetic resources to other countries and emphasizes the responsibility of organizations such as research institutions. $^{58}$

In general, the Draft is a legal reflection on the "post-epidemic era," in which the Draft expresses the legislator's respect for the needs of public health, public awareness, and concept requirements. From a macro point of view, it corrects to a certain extent the past attitude of "valuing utilization over protection" of wildlife resources, and at a deeper level the law has attempted to reconstruct the relationship between humans and wildlife after the epidemic; at the micro level, it improves specific regimes such as the habitat protection regime and quarantine regime, and builds new systems such as joint enforcement, investigation, and inspection system.

\section{Suggestions for the revisions of the final version of the Wildlife Protection Law}

\subsection{The revision should delete the provisions of state ownership of wildlife resources}

First, there is already a provision in the Property Law that wild animals belong to the State, ${ }^{59}$ and it is not appropriate to repeat this provision in the legislation. Secondly, the State mainly exercises the right of management and protection of wild animals, specifically the right of management of wild animals in the public interest, which is already reflected in the provisions of the law, and there is no need to stipulate it. Thirdly, State ownership of wildlife in the civil law sense contradicts the existing principle of compensation for damage caused by wildlife.

\subsection{The revision should establish a pluralistic system for wildlife protection}

\footnotetext{
${ }^{51}$ See Article 1 of the Draft:

http://www.npc.gov.cn/flcaw/userIndex.html?lid=ff808081752b7d43017543fdc24714c5;

Ecological civilization is a new social concept in China, which pursues the harmonious coexistence of human beings and the natural environment, with sustainable development as one of its main characteristics. See the website of Ministry of Environment of the People's Republic of China: http://www.mee.gov.cn/home/ztbd/sjhjr/0865/stwm/.

${ }^{52}$ See Article 2 of the Draft:

http://www.npc.gov.cn/flcaw/userIndex.html?lid=ff808081752b7d43017543fdc24714c5.

${ }^{53}$ See Article 10 of the Draft:

http://www.npc.gov.cn/flcaw/userIndex.html?lid=ff808081752b7d43017543fdc24714c5.

${ }^{54}$ See Article 10 of the Draft:

http://www.npc.gov.cn/flcaw/userIndex.html?lid=ff808081752b7d43017543fdc24714c5.

${ }^{55}$ See Article 11 of the Draft:

http://www.npc.gov.cn/flcaw/userIndex.html?lid=ff808081752b7d43017543fdc24714c5.

${ }^{56}$ See Article 13 of the Draft:

http://www.npc.gov.cn/flcaw/userIndex.html?lid=ff808081752b7d43017543fdc24714c5.

57 See Article 29 of the Draft:

http://www.npc.gov.cn/flcaw/userIndex.html?lid=ff808081752b7d43017543fdc24714c5.

${ }^{58}$ See Article 38 of the Draft:

http://www.npc.gov.cn/flcaw/userIndex.html?lid=ff808081752b7d43017543fdc24714c5.

${ }^{59}$ See Property Rights Law of the People's Republic of China (2007): https://www.pkulaw.com/CLI.1.89386.
} 
In addition to improving the management of the Wildlife Protection Law, people's governments at all levels should give full play to the power of social organizations and volunteers to build a diversified protection system. This is because, on the one hand, with the gradual increase in the level of civilization of Chinese society, social organizations and volunteers already have a strong will, sufficient energy, and sufficient financial resources to protect wildlife, which can, to a certain extent, reduce the Government's operating costs and work difficulties.

It is extremely difficult to establish a unified protection regime in such a large multi-ethnic country, so further institutional design is needed to coordinate the religious traditions and dietary habits of various ethnic groups. Unfortunately, the Draft does not recognize the status of social organizations and civil society forces, and in the final version it should be innovative and leading to explore the construction of a government-led wildlife protection mechanism, supplemented by social organizations and public participation.

\subsection{The revision should rationalize the penalty}

Most of the penalties in China's wildlife protection laws involve a fine regime. ${ }^{60}$ In order to eliminate the economic hunting of wildlife, the fines for related crimes should be raised significantly to reverse the Chinese people's belief that animals are resources to use recklessly.

The revision of the Wildlife Protection Law should clearly stipulate the legal liability for the transmission of viruses or even major public health incidents resulting from the trade in and consumption of wildlife, as the Criminal Law already provides that the crime of "selling, purchasing or using key State protected wildlife and their products" does not adequately anticipate the consequences of the perpetrator's actions in bringing about major public health incidents. ${ }^{61}$

Existing penalty is based on the economic value of wildlife, which faces the problem of legal ambiguity in the enforcement process. This is because the price can be understood both in terms of the purchase price and the government's valuation. If future legislation adopts a model of a total ban on wildlife trade, then the government's valuation should prevail.

\subsection{The revision should harmonize the Wildlife Protection Law with other legislation}

Article 25 of the TCM Law provides for the encouragement and support of wildlife breeding, and it will be a difficult issue to converge with the Wildlife Protection Law. ${ }^{62}$

And while national park legislation is still in the draft stage, Article 12 of the General Plan for Reform of the Ecological Civilization System already makes relevant provisions: "Establish a national park system. Strengthen the protection and sustainable use of important ecosystems... to build a long-term mechanism for the protection of rare wild animals and plants." ${ }^{63}$ In addition, General Secretary Xi also emphasized at a meeting of the Central Leading Group on Finance and Economy that "national parks should be integrated to better protect rare and endangered animals." ${ }^{64}$ In the next step of the legislative work of national parks, special attention should be paid to the protection of wildlife habitats.

Legislation on genetic resources currently has the Regulations of the People's Republic of China on the Management of Human Genetic Resources, ${ }^{65}$ the Measures for Approval of the Entry and Exit of Livestock and Poultry Genetic Resources and Foreign Cooperative Research and Utilization and other related legislation. ${ }^{66}$ Biodiversity protection is the direction of development of the Wildlife Protection Law, and the interface between genetic resources legislation and the Wildlife Protection Law should also be strengthened in terms of biodiversity protection. The Wildlife Protection Law should assume the overarching position of coordinating the various laws and highlight references to and application of the above-mentioned laws in specific provisions to build the interconnectedness of the legal system. It should be recognized that wildlife law is not only aimed at the public, but also at the judges who make decisions in the actual administration of

60 See Article 44-49 and 51-55 of the Wildlife Protection Law of the People's Republic of China (2018): http://www.gov.cn/bumenfuwu/2012-11/13/content_2601275.htm

${ }^{61}$ See Article 341 of Criminal Law of the People's Republic of China (2017): https://www.pkulaw.com/CLI.1.256346.

${ }^{62}$ See Article 25 of the Traditional Medicine Law (2017): https://www.pkulaw.com/CLI.1.287286.

63 See Article 12 of the General Plan for Reform of the Ecological Civilization System (2015): https://www.pkulaw.com/CLI.16.257357

${ }^{64}$ See Xinhua reported on January 26, 2016: http://www.xinhuanet.com/politics/2016-01/26/c_1117904083.htm

65 See the People's Republic of China on the Management of Human Genetic Resources (2019): https://www.pkulaw.comCLI.2.333002

${ }^{66}$ See the Measures for Approval of the Entry and Exit of Livestock and Poultry Genetic Resources and Foreign Cooperative Research and Utilization (2008): https://www.pkulaw.com/CLI.2.108196 
justice. In fact, the protection of wildlife relies heavily on the judicial activism of judges and the judicial system as a whole.

\subsection{The revisions should reflect animal welfare principles in specific regimes}

The revision of the Wildlife Protection Law is also an opportunity to improve animal welfare. However, in the Draft text, this activity is ad hoc, and the main purpose is to establish a public safety risk prevention system. In the Draft, although the focus on the ecological value of animal resources is increased, there is no breakthrough in terms of the welfare of individual animals.

For example, in the new Article 25 it is stipulated that "if capture is required for scientific research, artificial breeding, public exhibition, cultural relics protection or other special circumstances, it shall be reported to the wildlife protection department of the local government at or above the county level for approval." ${ }^{67}$ Article 28 also allows the sale, purchase, use of state-protected wildlife source and their products for the same purpose, but need to obtain approval and the corresponding special identification. ${ }^{68}$

The harm caused to animals by animal performances, as a backward and distorted entertainment consumption activity, should be prohibited by law. According to a survey conducted by the China Zoo Watch team, animal performances have existed in more than $95 \%$ of China's zoos since $2003 .{ }^{69}$ Although there are documents advocating the cessation of animal cruelty performances,${ }^{70}$ firstly, such performances are not prohibited by strong legal enforcement documents and still exist in various places, and secondly, the public is often unaware of the harm that human actions can cause to animals, so it is difficult to define "cruelty performances." The Draft, while constructing a wildlife sheltering regime, should focus on the welfare of individual animals after sheltering. The Draft should pay more attention to the welfare of the sheltered animals.

Therefore, as a new overarching amendment to the Wildlife Protection Law, if adding "animal welfare" to the legal principles is not in line with the overall legislative framework, then the concept of animal welfare should be reflected in the specific regimes. First and foremost, "animal performances" should be removed from the law and should be expressly prohibited by law. In the regimes of transporting and sheltering wild animals, the corresponding animal welfare should also be realized. In terms of animal welfare, China's laboratory animal legislation is already relatively comprehensive. ${ }^{71}$

\section{Concluding remarks}

China's wildlife protection law has been criticized as a "wildlife utilization guide" by some animal protection NGOs. And the outbreak of the epidemic has reinforced public skepticism. Generally speaking, China's wildlife protection laws are "anthropocentric" in nature, but it's also the inherent humanism of the law that dictates this, and all we can do about it is a certain amount of moral introspection and humane care for animals. The Decision is an opportunity to reverse the dichotomy between humans and animals. Local legislation has already come into effect, such as in Zhuhai, Guangzhou, Shenzhen etc., but mainly in cities with higher levels of economic development, as changes to the wildlife legal regime need to be made gradually, especially in such a complex country as China. ${ }^{72}$ The related listing regime is also in the process of improvement. ${ }^{73}$ In order to prevent public health hazards and to protect animals, the reform of the Wildlife

\footnotetext{
${ }^{67}$ See Article 25 of the Draft:

http://www.npc.gov.cn/flcaw/userIndex.html?lid=ff808081752b7d43017543fdc24714c5.

${ }^{68}$ See Article 28 of the Draft:

http://www.npc.gov.cn/flcaw/userIndex.html?lid=ff808081752b7d43017543fdc24714c5.

${ }^{69}$ See:

ttps://tw.news.yahoo.com/\%E3\%80\%90\%E6\%9D\%B1\%E4\%BA\%9E\%E5\%B1\%95\%E6\%BC $\% 94 \% \mathrm{E} 5 \% 8 \mathrm{~B} \% 95 \% \mathrm{E} 7 \% 89 \% \mathrm{~A} 9 \% \mathrm{E}$ 8\%A7\%80\%Е5\%AF\%9F\%E3\%80\%91\%Е7\%B3\%BB\%Е5\%88\%9701-\%Е2\%94\%80-

\%Е4\%B8\%AD\%E5\%9C\%8B\%E5\%85\%89\%E6\%80\%AA\%E9\%99\%B8\%Е9\%9B\%A2\%E3\%80\%81\%Е8\%99\%90105530960.html.

${ }^{70}$ See the Ministry of Housing and Urban-Rural Development Circular on the Issuance of the National Zoo Development Outline (2013): www.gov.cn.zwgk/2013-07/03/content_2439496.htm.

${ }^{71}$ For a detailed discussion, see: GAO, L. The laboratory animal legal system of China, dA. Derecho Animal (Forum of Animal Law Studies) 11/2 (2020) 30-39.

${ }^{72}$ See Guangzhou Regulations on Prohibition of Unbridled Consumption of Wild Animals (2020.6.1), Zhuhai Special Economic Zone Regulations on Prohibition of Unbridled Consumption of Wild Animals (2020.5.1), Shenzhen Special Economic Zone Comprehensive Wildlife Prohibition Regulations (2020.5.1) etc.:

https://www.pkulaw.com/CLI.10.1596042;

https://www.pkulaw.com/CLI.10.1582405;

http://sz.people.com.cn/n2/2020/0402/c202846-33921287.html.

${ }^{73}$ See Ministry of Agriculture and Rural Affairs of the People's Republic of China, National Catalogue of Livestock and Poultry
} 
Protection Law must have the effect of setting a non-anthropocentric tone. The introduction of the Draft shows the legislator's timely feedback after learning from experience, and has made significant progress in legislative concepts, legal principles, and the construction of specific regimes. However, there are still areas that need further improvement. In general, after the legislation, the focus is on the operation of the enforcement mechanism and the promotion of judicial power.

Genetic Resources: http://www.moa.gov.cn/gk/tzgg_1/tz/202005/t20200529_6345586.htm. It publishes local breeds, cultivars and supporting lines, introduced breeds and supporting lines for 33 existing species of livestock and poultry and total 897 above. The animals on the list are edible and are otherwise inedible. 


\section{Annex 1}

Table 1: National laws related to wildlife protection in China

\begin{tabular}{|c|c|c|}
\hline Name of law & Key Animal-Related Content & Date of introduction and revision \\
\hline Wildlife protection law ${ }^{74}$ & $\begin{array}{c}\text { Wildlife protection and } \\
\text { utilization }\end{array}$ & $1988 / 2004 / 2009 / 2016 / 2018$ \\
\hline $\begin{array}{l}\text { Implementing Regulations on } \\
\text { the Protection of Aquatic } \\
\text { Wildlife }\end{array}$ & $\begin{array}{c}\text { Aquatic Wildlife protection and } \\
\text { utilization }\end{array}$ & $1993 / 2011 / 2013$ \\
\hline $\begin{array}{c}\text { Implementing Regulations on } \\
\text { the Protection of Terrestrial } \\
\text { Wildlife }^{76}\end{array}$ & $\begin{array}{l}\text { Terrestrial Wildlife protection } \\
\text { and utilization }\end{array}$ & $1992 / 2011 / 2016$ \\
\hline $\begin{array}{l}\text { Animal Epidemic Prevention } \\
\text { Law }^{77}\end{array}$ & $\begin{array}{l}\text { Prevention, control and } \\
\text { eradication of animal diseases }\end{array}$ & $1998 / 2008 / 2013$ \\
\hline Environmental Protection Law ${ }^{78}$ & $\begin{array}{l}\text { Ecological environment } \\
\text { protection }\end{array}$ & $1989 / 2014$ \\
\hline Fisheries law $^{79}$ & $\begin{array}{l}\text { Strengthening the protection, } \\
\text { enhancement, development and } \\
\text { rational use of fishery resources } \\
\text { and developing artificial } \\
\text { breeding }\end{array}$ & $1986 / 2000 / 2004 / 2009 / 2013$ \\
\hline Husbandry law ${ }^{80}$ & $\begin{array}{c}\text { Management and utilization of } \\
\text { livestock and poultry genetic } \\
\text { resources }\end{array}$ & $2005 / 2015$ \\
\hline $\begin{array}{l}\text { National Forest Park } \\
\text { Management Law }\end{array}$ & Wildlife habitat protection & 2011 \\
\hline $\begin{array}{c}\text { Wetland Protection and } \\
\text { Management Regulation }^{82}\end{array}$ & Wildlife habitat protection & 2013 \\
\hline Criminal law $^{83}$ & $\begin{array}{l}\text { Combating wildlife-related } \\
\text { crime }\end{array}$ & 1997-2017 (10 revisions) \\
\hline
\end{tabular}

\footnotetext{
${ }^{74}$ See the Wildlife Protection Law of the People's Republic of China (2018): http://www.gov.cn/bumenfuwu/201211/13/content_2601275.htm.

${ }^{75}$ See Implementing Regulations on the Protection of Aquatic Wildlife (2013): https://www.pkulaw.com/CLI.2.214787.

${ }_{76}$ See Implementing Regulations on the Protection of Terrestrial Wildlife (2016): https://www.pkulaw.com/CLI.2.269317.

${ }^{77}$ See Animal Epidemic Prevention Law (2015): https://www.pkulaw.com/CLI.1.252610.

${ }^{78}$ See Environmental Protection Law (2014): https://www.pkulaw.com/ CLI.1.223979.

${ }^{79}$ See Fisheries law (2013): https://www.pkulaw.com/ CLI.1.223979.

${ }^{80}$ See Husbandry law (2015): https://www.pkulaw.com/ CLI.1.252631.

${ }^{81}$ See National Forest Park Management Law (2011): https://www.pkulaw.com/ CLI.4.155492.

${ }^{82}$ See Wetland Protection and Management Regulation (2013): https://www.pkulaw.com/ CLI.4.306334.

${ }^{83}$ See Criminal law (2017): https://www.pkulaw.com/ CLI.1.256346.

226 Derecho Animal. Forum of Animal Law Studies, vol. 11/4
} 